\title{
Potential Antifibrotic and Angiostatic Impact of Idebenone, Carnosine and Vitamin E in Nano-Sized Titanium Dioxide-Induced Liver Injury
}

\author{
Samy A. Abdelazima ${ }^{a}$ Hebatallah A. Darwish ${ }^{a}$ Sanaa A. Alib Maha Z. Rizk ${ }^{b}$ \\ Mai O. Kadry

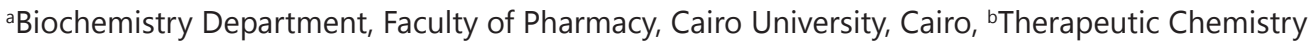 \\ Department, National Research Center, Dokki, Gizza, Egypt
}

\section{Key Words}

Nano-titanium dioxide $\cdot$ In vitro $\cdot$ VEGF and western blot

\begin{abstract}
Background/Aim: The present study investigated the in vitro and in vivo effects of individual and combined doses of idebenone, carnosine and vitamin $\mathrm{E}$ on ameliorating some of the biochemical indices of nano-sized titanium dioxide $\left(\mathrm{n}-\mathrm{TiO}_{2}\right)$ in mice liver. Methods: The in vitro cytotoxic effect of nano-sized anatase $\mathrm{TiO}_{2}(21 \mathrm{~nm}$ ) on hepatic cell lines (HepG 2) was investigated. Additionally, $\mathrm{n}-\mathrm{TiO}_{2}$ was orally administered $(150 \mathrm{mg} / \mathrm{kg} /$ day) for 2 weeks, followed by a daily intragastric gavage of the aforementioned antioxidants for 1 month. Results: $\mathrm{n}-\mathrm{TiO}_{2}$ induced significant cytotoxicity in hepatic cell lines and elevated the levels of serum alanine aminotransferase (ALT), aspartate aminotransferase (AST), hepatic total antioxidant capacity (TAC) and nitrite/nitrate (NOx) levels. Meanwhile, glutathione-S-transferase (GST) activity was significantly reduced. Moreover, RT-PCR and western blot analysis showed that $\mathrm{n}-\mathrm{TiO}_{2}$ significantly altered the mRNA and protein expressions of transforming growth factor-beta (TGF- $\beta 1$ ) and Smad-2, as well as vascular endothelium growth factor (VEGF). Histopathological examination of hepatic tissue reinforced these results. Conclusion: Idebenone, carnosine and vitamin $\mathrm{E}$ ameliorated the deviated parameters with the combination regimen demonstrating the most pronounced effect. Oxidative stress, liver fibrosis and angiogenesis may be implicated in $\mathrm{n}-\mathrm{TiO}_{2}$-induced liver toxicity.
\end{abstract}




\section{Cellular Physiology Cell Physiol Biochem 2015;35:2402-2411

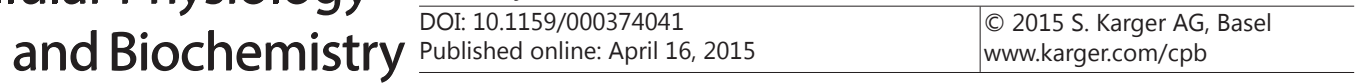 Abdelazim et al.: Smad-2 and TGF- $\beta 1$ and VEGF Signaling in $\mathrm{n}$ - $\mathrm{TiO}_{2}$ Induced Oxidative Injury}

\section{Introduction}

Metallic nanoparticles (NPs) are used in cosmetics, sunscreens, food products, implanted medical devices as cardiovascular stents, dental implants and spinal fixation devices. The success of engineered nanomaterials is due to their small size, large surface area, quantum size effects and high reactivity. However, the increasing use of these nano-materials has aroused global concern regarding their fate in biological systems [1, 2]. Therefore, it is important to clarify the effects of various NPs on organs health, as well as the pathogenic mechanisms involved.

Nano-sized titanium dioxide (n- $\mathrm{TiO}_{2}$ ), a widely used metallic NP, can accumulate in the lung, liver, spleen, heart, and brain, thereby increasing the production of reactive oxygen species (ROS), generating various inflammatory responses [3] and inducing apoptosis or necrosis [4]. Interestingly, $\mathrm{n}-\mathrm{TiO}_{2}$ is a potent inducer of transforming growth factor-beta (TGF- $\beta$ ) expression, partly via an interleukin-1 beta (IL-1 $\beta$ )-dependent mechanism [5]. $\mathrm{n}-\mathrm{TiO}_{2}$ also induced higher levels of transcription factors, Smads, and growth factors [6].

Alternative drugs from natural and synthetic antioxidants have attracted the interest of many researchers in this field due to the hazards of treatment failure, drug resistance and heavy costs associated with current hepatic therapy [7]. In this study, the efficacy of three antioxidants, either alone or in combination, has been tested against $\mathrm{n}-\mathrm{TiO}_{2}$-induced liver injury. Idebenone [2, 3-dimethoxy-5-methyl-6-(10-hydroxydecyl)-1,4 benzoquinone] is a synthetic analog of coenzyme Q10 (CoQ10), the vital cell membrane antioxidant and essential constituent of the ATP-producing mitochondrial electron transport chain (ETC) [8]. Idebenone is a potent antioxidant; it has the ability to operate under low oxygen tension situations and to cause inhibition of lipid peroxidation $[9,10]$. Carnosine ( $\beta$-alanylL-histidine) is highly concentrated in muscle and brain tissues. It is a potent and selective scavenger of unsaturated aldehydes [11]. Likewise, vitamin $\mathrm{E}$ is a chain-breaking antioxidant, which prevents the propagation of oxidative stress in biological membranes [12,13], inhibits hepatocarcinogenesis, abolishes inducible nitric oxide synthase (iNOS) expression and suppresses TGF- $\alpha[14]$.

\section{Materials and Methods}

\section{Chemicals}

Titanium dioxide nanoparticles (particle size $21 \mathrm{~nm}$ ), idebenone, carnosine and vitamin E were purchased from Sigma-Aldrich Co (St. Louis, MO, USA). $\mathrm{TiO}_{2}$ NPs were suspended in $1 \%$ tween 80 and dispersed by ultrasonic vibration for $15 \mathrm{~min}$. The size distribution of the NPs in the suspension (hydrodynamic size) and the zeta potential were analyzed with a Brookhaven 90 Plus particle size analyzer. Scanning electron microscopy (SEM) was used to evaluate size of $\mathrm{TiO}_{2} \mathrm{NPs}$.

\section{Animals}

Male Wistar albino mice, weighing 20 -25 gm, obtained from the animal house of National Research Center were kept at standardized conditions. They were allowed free access to water and standard chow diet. All procedures relating to animal care strictly adhered to the ethical procedures approved by Animal Care and Use Committee of Faculty of Pharmacy, Cairo University and comply with the Guide for Care and Use of Laboratory published by the US National Institute of Health (NIH publication No. 85-23, revised 1996).

\section{Experimental Design}

After 1 week of acclimatization, animals were divided into six groups, 20 mice each.

Group1: Animals received tween $-80(5 \mathrm{mg} / \mathrm{kg})$ and served as control group. Groups from 2 to 6 : Animals were given a daily oral dose of n-TiO2 (150 mg/ Kg) for 2 weeks [15] then the following regimen was applied: Groups 3, 4, 5 and 6 were respectively treated with idebenone (200 $\mathrm{mg} / \mathrm{Kg}$ ) daily [16], carnosine (200 mg/Kg) daily [17], vitamin E (100mg/Kg) daily [18] and a combination of the three antioxidants with the same dose regimen. 


\section{Cellular Physiology Cell Physiol Biochem 2015;35:2402-2411 \begin{tabular}{l|l} 
and Biochemistry Published online: April 16, 2015 & $\begin{array}{l}\text { C) 2015 S. Karger AG, Basel } \\
\text { www.karger.com/cpb }\end{array}$ \\
\hline
\end{tabular} \\ Abdelazim et al.: Smad-2 and TGF- $\beta 1$ and VEGF Signaling in $\mathrm{n}-\mathrm{TiO}_{2}$ Induced Oxidative Injury}

The afore-mentioned antioxidants were suspended in tween-80 and given to animals through intragastric gavages. Treatment was carried out for 1 month after n- $\mathrm{TiO}_{2}$-intoxication.

Blood sampling and liver tissue preparation

24 hours following the last administered dose, mice were sacrificed; the blood was collected from the sublingual vein and serum was separated. Then livers were harvested, washed with saline and weighed. They were homogenized in 4 volumes of phosphate buffer, pH 7.4. for biochemical determinations. The remaining part was divided into three portions for western blot, PCR analysis as well as histopathological examination.

\section{Measured parameters}

Cytotoxic effect on hepatic human cell line (HepG 2). Cell viability was assessed by the mitochondrial dependent reduction of yellow MTT (3-(4,5-dimethylthiazol-2-yl)-2,5-diphenyl tetrazolium bromide) to purple formazan. Cells were suspended in RPMI 1640 medium for HepG2. The media were supplemented with $1 \%$ antibiotic-antimycotic mixture, $1 \%$ L-glutamine and $10 \%$ fetal bovine serum and kept at $37{ }^{\circ} \mathrm{C}$ under $5 \% \mathrm{CO}_{2}$ then cultured 10 days, seeded at concentration of $10 \times 10^{3}$ cells/well in fresh complete growth medium at $37^{\circ} \mathrm{C}$ for $24 \mathrm{~h}$ under $5 \% \mathrm{CO}_{2} .40 \mathrm{ul} \mathrm{MTT}$ salt $(2.5 \mu \mathrm{g} / \mathrm{ml})$ were added and incubated for $4 \mathrm{hr}$ at $37^{\circ} \mathrm{C}$ under $5 \% \mathrm{CO}_{2}$ followed by $10 \%$ Sodium dodecyl sulphate in deionized water. DMSO is the used vehicle [19].

Serum alanine and aspartate aminotransferases (ALT\&AST) activities. They were estimated spectrophotometrically according to the method of Reitman and Frankle [20] using diagnostic kits provided by Randox Company.

Hepatic total antioxidant capacity (TAC) level. It was estimated according to manufacturer's instructions using Randox kits [21]. Hepatic glutathione-S-transferase (GST) activity. It was estimated according to manufacturer's instructions using Randox kits [22].

Hepatic total Nitrite/Nitrate (NOx) level. It was measured according to the method of Miranda et al., [23] using kit provided by Randox Company. The method employs the reduction of any nitrate to nitrite by vanadium chloride followed by detection of total nitrite by Griess reagent at $540 \mathrm{~nm}$.

Quantitative real-time polymerase chain reaction ( $q R T-P C R$ ) for analysis of hepatic TGF- $\beta 1$, Smad-2 and VEGF MRNA expressions

Total RNA was isolated using Tripure Isolation Reagent (Roche) according to the manufacturer's instructions. Complementary DNA (cDNA) was generated using Superscript Choice systems (Life Technolgies, Breda, Netherlands) according to the manufacturer's instructions. To assess the mRNA expression of TGF- $\beta 1$, Smad-2 and VEGF, RT-PCR was performed using SYBR green PCR Master mix (Applied Biosystems, CA, USA) as described by the manufacturer. All primers were purchased from Shine Gene (China).The temperature profile was as follows: $94^{\circ} \mathrm{C}$ for $3 \mathrm{~min}, 94^{\circ} \mathrm{C}$ for $20 \mathrm{sec}, 60^{\circ} \mathrm{C}$ for $20 \mathrm{sec}$ and $72^{\circ} \mathrm{C}$ for $20 \mathrm{sec}$ for $35 \mathrm{cycles}$. The values of RT-PCR products were normalized with respect to endogenous $\beta$-actin product levels [24]. Primers were represented in Table 1.

Western blot of hepatic TGF- $\beta 1$, Smad-2 and VEGF protein expressions

A Part of liver was homogenized in lysis buffer and centrifuged at $14,000 \mathrm{rpm}$ for $15 \mathrm{~min}$ at $4^{\circ} \mathrm{C}$. Proteins were separated using 10\% sodium dodecyl sulphate polyacrylamide gel electrophoresis (SDS-PAGE). The gel was transferred onto a nitrocellulose membrane which was blocked with $5 \% \mathrm{w} / \mathrm{v}$ nonfat dry milk and incubated overnight with the specific primary antibodies (TGF- $\beta 1$, Smad-2, VEGF). The membranes were

Table 1. RT- PCR primers used in the gene expression analysis

\begin{tabular}{llc}
\hline Gene name & Primer sequence & Primer size (bp) \\
\hline$\beta$-actin & F GAGACCTTCAACACCCCAGC & 263 \\
& R ATGTCACGCACGATTTCCC & \\
Smad-2 & F-TCTCCGGCTGAACTGTCTCCTA & 267 \\
& R-GCGATTGAACACCAGAATGCA & \\
TGF- $\beta 1$ & F-TGCTAATGGTGGACCGCAA & 329 \\
& R-CACTGCTTCCCGAATGTCTGA & \\
VEGF & F-TGTACCTCCACCATGCCAAGT & 480 \\
& R-TGGTAGAC-GTCCATGAACTTG & \\
\hline
\end{tabular}




\section{Cellular Physiology Cell Physiol Biochem 2015;35:2402-2411 \\ \begin{tabular}{ll|l} 
and $10.1159 / 000374041$ & \\
and Biochemistry & $\begin{array}{l}\text { O 2015 S. Karger AG, Basel } \\
\text { www.karger.com/cpb }\end{array}$ \\
\cline { 2 - 3 }
\end{tabular} \\ Abdelazim et al.: Smad-2 and TGF- $\beta 1$ and VEGF Signaling in $\mathrm{n}-\mathrm{TiO}_{2}$ Induced Oxidative Injury}

then probed with horseradish peroxidase conjugated secondary antibodies. Immunoreactive bands were visualized by enhanced chemiluminescence and quantified by densitometry [25].

\section{Histopathological Examination}

Liver specimens were fixed in 10\% formaldehyde for $24 \mathrm{hr}$, and then processed for embedding in paraffin. Sections of $4 \mu \mathrm{m}$ were stained with Masson's Trichrome stain and examined under light microscope for collagen fiber contents [26].

\section{Statistical Analysis}

Data were expressed as the mean \pm S.E.M. Statistical analysis was performed using Instat-3 computer program (Graph pad software Inc, San Diego, CA, USA). One way analysis of variance (ANOVA) by SPSS 12 program followed by Post HOC and turkey's test were used to determine the differences between means of different groups. The level of significance was set at p-value $<0.05$.

\section{Results}

\section{Characterization studies}

Characterization studies of $\mathrm{n}-\mathrm{TiO}_{2}$ revealed that the mean hydrodynamic diameter and zeta potential of the NPs suspension were $24.27 \pm 1.5 \mathrm{~nm}$ and $-11.1 \pm 1 \mathrm{mV}$, respectively. The average size reported by SEM was $21 \pm 12 \mathrm{~nm}$. Only $56 \pm 6 \%$ of particles possessed this size; remaining particles were agglomerates ranging from 100 to $200 \mathrm{~nm}$. Figure 1 representative SEM image of n-TiO ${ }_{2}$.

\section{Cytotoxic effect on HepG 2 cell lines}

$\mathrm{n}-\mathrm{TiO}_{2}$ increased cytotoxicity by $407 \%$ while idebenone, carnosine, vitamin $\mathrm{E}$ and their combination reduced the cytotoxicity by $71 \%, 22 \%, 39 \%$ and $100 \%$ at $100 \mathrm{ppm}$, respectively implying the hepatotoxic effect of $\mathrm{n}-\mathrm{TiO}_{2}$ particles and the hepatoprotective effect of these antioxidants especially idebenone and the combination regimen.

Fig. 1. $\mathrm{n}-\mathrm{TiO}_{2}$ characterization by scanning electron microscope (SEM).

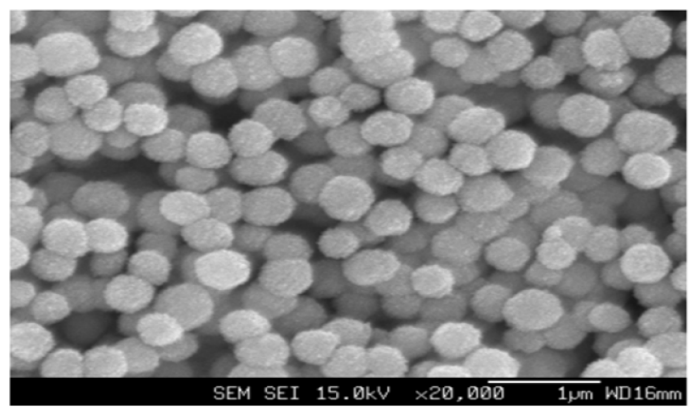

Table 2. Effect of idebenone (ID), carnosine (CR), vitamin E (Vit.E) and their combination on relative liver weight as well as serum aminotransferases activities in $\mathrm{n}^{-\mathrm{TiO}_{2}}$ - induced liver damage. Data were expressed as means \pm S.E.M $(n=10)$. Groups having similar letters are not significantly different and those having different letters are significantly different. RLW: relative liver weight, ALT: alanine aminotransferase, AST: aspartate aminotransferase.

\begin{tabular}{lllllll}
\hline Parameter & Control & $\mathrm{nTiO}_{2}$ & $\mathrm{nTiO}_{2}+\mathrm{ID}$ & $\mathrm{nTiO}_{2}+\mathrm{CR}$ & $\mathrm{nTiO}_{2}+\mathrm{Vit}^{\mathrm{E}}$ & $\mathrm{nTiO}_{2}+\mathrm{Comb}$ \\
\hline $\mathrm{RLW}(g \%)$ & $5.48 \pm 0.02^{\mathrm{a}}$ & $6.3 \pm 0.03^{\mathrm{b}}$ & $5.47 \pm 0.01^{\mathrm{a}}$ & $5.5 \pm 0.01^{\mathrm{a}}$ & $5.49 \pm 0.02^{\mathrm{a}}$ & $5.5 \pm 0.01^{\mathrm{a}}$ \\
$\mathrm{ALT}(U / L)$ & $14.5 \pm 0.25^{\mathrm{a}}$ & $22.8 \pm 0.75^{\mathrm{b}}$ & $16.2 \pm 0.28^{\mathrm{c}}$ & $18.1 \pm 0.18^{\mathrm{d}}$ & $20.01 \pm 0.14^{\mathrm{d}}$ & $15.1 \pm 0.15^{\mathrm{a}}$ \\
$\mathrm{AST}(U / L)$ & $32.4 \pm 0.2^{\mathrm{a}}$ & $45.8 \pm 0.17^{\mathrm{b}}$ & $42.2 \pm 0.16^{\mathrm{c}}$ & $41.3 \pm 0.14^{\mathrm{c}}$ & $42.27 \pm 0.09^{\mathrm{c}}$ & $32.9 \pm 0.14^{\mathrm{a}}$ \\
\hline
\end{tabular}




\section{Cellular Physiology Cell Physiol Biochem 2015;35:2402-2411 \begin{tabular}{ll|l} 
and $10.1159 / 000374041$ & $\begin{array}{l}\text { O 2015 S. Karger AG, Basel } \\
\text { www.karger.com/cpb }\end{array}$ \\
\hline
\end{tabular} Abdelazim et al.: Smad-2 and TGF- $\beta 1$ and VEGF Signaling in $\mathrm{n}-\mathrm{TiO}_{2}$ Induced Oxidative Injury}

Table 3. Effect of idebenone (ID), carnosine (CR), vitamin E (Vit. E) and their combination on hepatic total antioxidant capacity, glutathione-S-transferase activity and nitrite/nitrate level in $\mathrm{n}-\mathrm{TiO}_{2}$ - induced liver damage. Data were expressed as means \pm S.E.M $(n=10)$, Groups having similar letters are not significantly different and those having different letters are significantly different. TAC: total antioxidant capacity GST: glutathione-s-transferase, NOx: nitrite/nitrate

\begin{tabular}{|c|c|c|c|c|c|c|}
\hline Parameter & Control & $\mathrm{nTiO}_{2}$ & $\mathrm{nTiO}_{2}+\mathrm{ID}$ & $\mathrm{nTiO}_{2}+\mathrm{CR}$ & nTiO $_{2}+$ Vit. E & $\mathrm{nTiO}_{2}+\mathrm{Comb}$ \\
\hline $\begin{array}{l}\text { TAC } \\
(\mu \mathrm{mol} / \mathrm{g} \text { tissue })\end{array}$ & $3.935 \pm 0.18^{a}$ & $15.42 \pm 0.11^{b}$ & $5.44 \pm 0.14^{c}$ & $5.07 \pm 0.12^{c}$ & $6.52 \pm 0.19^{c}$ & $4.02 \pm 0.195^{a}$ \\
\hline $\begin{array}{l}\text { GST } \\
(\mu \mathrm{mol} / \mathrm{mg} \text { protein })\end{array}$ & $4.92 \pm 0.01$ & $1.51 \pm 0.01^{b}$ & $3.61 \pm 0.01^{c}$ & $2.34 \pm 0.02^{b}$ & $3.4 \pm 0.017 c$ & $3.99 \pm 0.019$ \\
\hline $\begin{array}{l}\mathrm{NOx} \\
(\mu \mathrm{mol} / \mathrm{g} \text { tissue })\end{array}$ & $2.14 \pm 0.11^{a}$ & $9.99 \pm 0.09 b$ & $5.67 \pm 0.14 \mathrm{c}$ & $5.04 \pm 0.10^{c}$ & $4.95 \pm 0.12^{\mathrm{c}}$ & $3.32 \pm 0.11^{\mathrm{a}}$ \\
\hline
\end{tabular}

Table 4. Effect of idebenone (ID), carnosine (CR), vitamin E (Vit. E) and their combination on mRNA protein expression of TGF- $\beta$, Smad- 2 and VEGF in $n-T_{2}$ - induced liver damage. Data were expressed as mean \pm S.E.M $(n=10)$, Groups having similar letters are not significantly different and those having different letters are significantly different.. TGF-ß: transforming growth factor beta, VEGF: vascular endothelium growth factor

\begin{tabular}{lllllll}
\hline Parameter & Control & $\mathrm{nTiO}_{2}$ & $\mathrm{nTiO}_{2}+\mathrm{ID}$ & $\mathrm{nTiO}_{2}+\mathrm{CR}$ & $\mathrm{nTiO}_{2}+\mathrm{Vit} . \mathrm{E}$ & $\mathrm{nTiO}_{2}+\mathrm{Comb}$ \\
\hline TGF- $\beta$ & $1.6 \pm 0.18^{\mathrm{a}}$ & $7.42 \pm 0.11^{\mathrm{b}}$ & $2.94 \pm 0.14^{\mathrm{c}}$ & $3.67 \pm 0.12^{\mathrm{c}}$ & $2.52 \pm 0.19^{\mathrm{c}}$ & $2.02 \pm 0.195^{\mathrm{a}}$ \\
Smad-2 & $25.5 \pm 2.1^{\mathrm{a}}$ & $104.5 \pm 5.5^{\mathrm{b}}$ & $60.6 \pm 5.9^{\mathrm{c}}$ & $74.7 \pm 6.2^{\mathrm{d}}$ & $52.4 \pm 4.7^{\mathrm{c}}$ & $50.21 \pm 3.1^{\mathrm{c}}$ \\
VEGF & $10.8 \pm 0.9^{\mathrm{a}}$ & $43.8 \pm 1.9^{\mathrm{b}}$ & $16.71 \pm 0.8^{\mathrm{c}}$ & $28.42 \pm 1.3^{\mathrm{d}}$ & $19.95 \pm 1.1^{\mathrm{e}}$ & $15.20 \pm 1.2^{\mathrm{c}}$ \\
\hline
\end{tabular}

Inhibition of n-TiO2 induced liver injury

$\mathrm{n}-\mathrm{TiO}_{2}$ increased significantly the relative liver weight as well as serum levels of ALT and AST as compared with the control values (Table 2). On the other hand, idebenone, carnosine, vitamin $\mathrm{E}$, significantly reduced these parameters relative to $\mathrm{n}-\mathrm{TiO}_{2}$ intoxicated group. The tested parameters were reverted back to near normal when the three antioxidants were administered in combination.

Modulation of oxidative stress biomarkers

$\mathrm{n}-\mathrm{TiO}_{2}$ intoxication induced a state of oxidative stress evidenced by a reduction of liver GST along with an increment of (TAC and NOx) levels as compared with control (Table 3). Administration of idebenone, carnosine, vitamin E or their combination significantly elevated GST activity as compared with intoxicated animals. Meanwhile, the TAC and NOx values were decreased following these antioxidants with the combination regimen displaying the most pronounced effect relative to $\mathrm{n}-\mathrm{TiO}_{2}$.

qRT-PCR and western blot (Table 4 and Fig. 2, 3) revealed that $\mathrm{n}-\mathrm{TiO}_{2}$ up- regulated mRNA and protein expression of TGF- $\beta 1$, Smad-2 and VEGF by almost 4.6, 4.09, 4.05 and $9.07,9.26,10.4$ folds respectively, as compared with the control value. Administration of idebenone, carnosine, and vitamin E noticeably down-regulated their expression level with the combination regimen showing the most significant effect in comparison with animals intoxicated by $\mathrm{n}-\mathrm{TiO}_{2}$.

\section{Histopathological findings}

Figure 4 showed that $\mathrm{n}-\mathrm{TiO}_{2}$ intoxicated group displayed severe fibrosis with massive collagen fiber infiltration (B). Idebenone and carnosine groups showed some collagenous fibers in the portal area ( $C$ and $D)$. On the other hand, mice treated with vitamin $E$ showed very little collagen fibers (E). Apparently normal liver architecture was seen in the combination group (F).

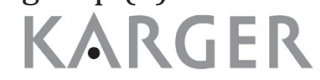




\section{Cellular Physiology Cell Physiol Biochem 2015;35:2402-2411 \begin{tabular}{ll|l} 
DOI: 10.1159/000374041 & $\begin{array}{l}\text { O 2015 S. Karger AG, Basel } \\
\text { www.karger.com/cpb }\end{array}$ \\
\hline
\end{tabular} \\ Abdelazim et al.: Smad-2 and TGF- $\beta 1$ and VEGF Signaling in $\mathrm{n}$ - $\mathrm{TiO}_{2}$ Induced Oxidative Injury}

Fig. 2. Western blot analysis showing protein expression of TGF- $\beta$, Smad-2, VEGF compared with $\beta$ actin in different studied groups.

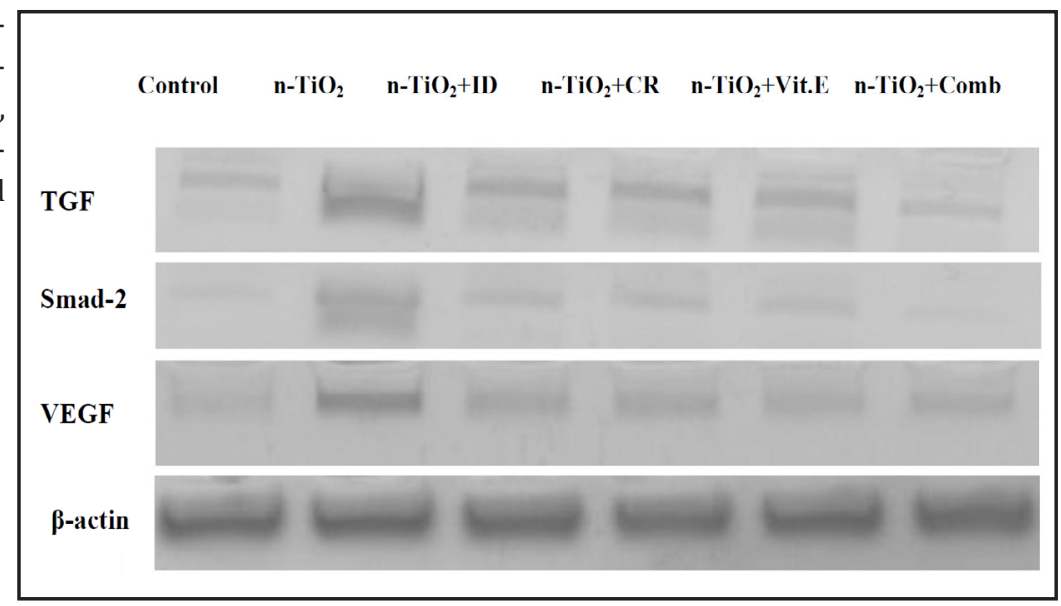

Fig.3. Western blot showing the effect of idebenone, carnosine, vitamin $\mathrm{E}$ and their combination on protein expression of TGF- $\beta 1$, Smad- 2 and VEGF. $\beta$-actin was used as an internal control. Data are expressed as fold change \pm S.E.M $(n=10)$.p-value $<0.05$ is considered significant. Groups having the same letter are not significantly different from each other, while those having different letters are significantly different from each other.

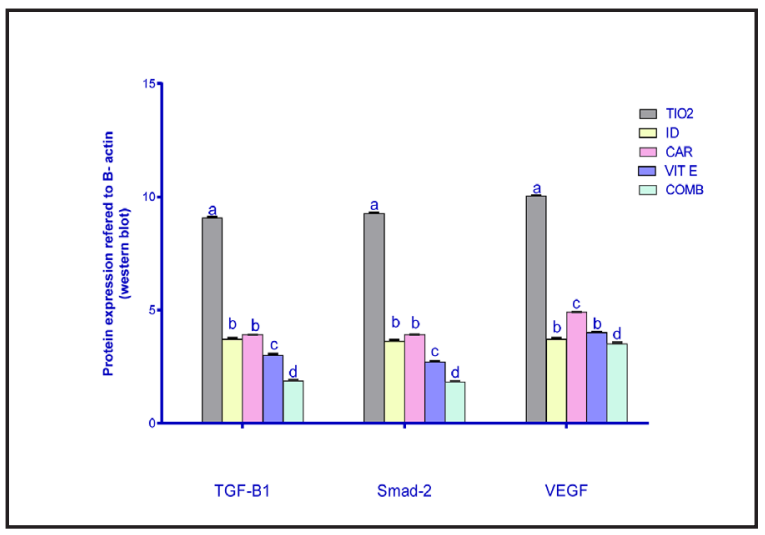

\section{Discussion}

Studies have described several toxic effects due to anatase $\mathrm{n}-\mathrm{TiO}_{2}$ relative to other forms. In fact, anatase $\mathrm{n}-\mathrm{TiO}_{2}$ produces greater responses, particularly a reduction in cell viability and an increase in inflammatory indices and ROS generation.

The current study revealed that $\mathrm{TiO}_{2}$ induced liver damage, both in vivo and in vitro, and that idebenone, carnosine, vitamin E, and their combination alleviated that damage. This finding demonstrated that the liver is one of the target organs of NPs toxicity. Previously, liver damage was induced by excess oral titanium powder administration, boosting the ALT/ AST ratio, the activity of lactate dehydrogenase, liver weight, and the induction of hepatocyte necrosis $[27,28]$. Elevated levels of ALT and AST in $\mathrm{n}-\mathrm{TiO}_{2}$ group indicated cellular leakage and loss of functional integrity of cell membranes in the liver [4]. Moreover, increased relative liver weight could be attributed to $\mathrm{TiO}_{2}$ accumulation in liver tissue. On the other hand, the reduction in hepatic enzyme levels following the administration of these antioxidants implied their possible protective effect on hepatocytes. In agreement, idebenone was reported to protect against bile acid-induced hepatocellular injury and lipid peroxidation [10]. Carnosine protected the liver against ischemia and lowered the markers of liver damage (ALT, AST and myeloperoxidase) [29]. Similarly, the protective effect of vitamin E against hepatic tissue injury was previously documented [30].

$\mathrm{n}-\mathrm{TiO}_{2}$ triggered an oxidative attack that was represented by an elevation in TAC and a reduction of the antioxidative defense mechanism represented by GST [31]. n- $\mathrm{TiO}_{2}$ was found to release ROS $\left(\bullet \mathrm{OH}\right.$ and $\mathrm{O}_{2}{ }^{--}$). The interaction between $\mathrm{H}_{2} \mathrm{O}_{2}$ and $\mathrm{O}_{2}{ }^{--}$can create $\bullet \mathrm{OH}$ and $10_{2}$, which are far more destructive and can peroxidize the unsaturated lipids of the cell membrane [32]. Treatment with idebenone, carnosine, vitamin E and their combination alleviated these changes to a variable degree. Previously, idebenone has been shown to protect against hepatocellular injury and prevent hydroperoxide production [10]. Carnosine 


\section{Cellular Physiology Cell Physiol Biochem 2015;35:2402-2411 \begin{tabular}{l|l} 
and Biochemistry Published online: April 16, 2015 & $\begin{array}{l}\text { C) 2015 S. Karger AG, Basel } \\
\text { www.karger.com/cpb }\end{array}$ \\
\hline
\end{tabular} \\ Abdelazim et al.: Smad-2 and TGF- $\beta 1$ and VEGF Signaling in $\mathrm{n}-\mathrm{TiO}_{2}$ Induced Oxidative Injury}

Fig. 4. Liver sections stained with Masson's trichrome, scale bare $=50 \mu \mathrm{m}(\mathrm{A})$ Control group (B) $\mathrm{n}-\mathrm{TiO}_{2}$ group (C) $\mathrm{n}-\mathrm{TiO}_{2}$ and idebenone group (D) $\mathrm{n}-\mathrm{TiO}_{2}$ and carnosine group (E) $\mathrm{n}-\mathrm{TiO}_{2}$ and vitamin E group (F) n-TiO2 and the combination of idebenone, carnosine and vitamin E group.
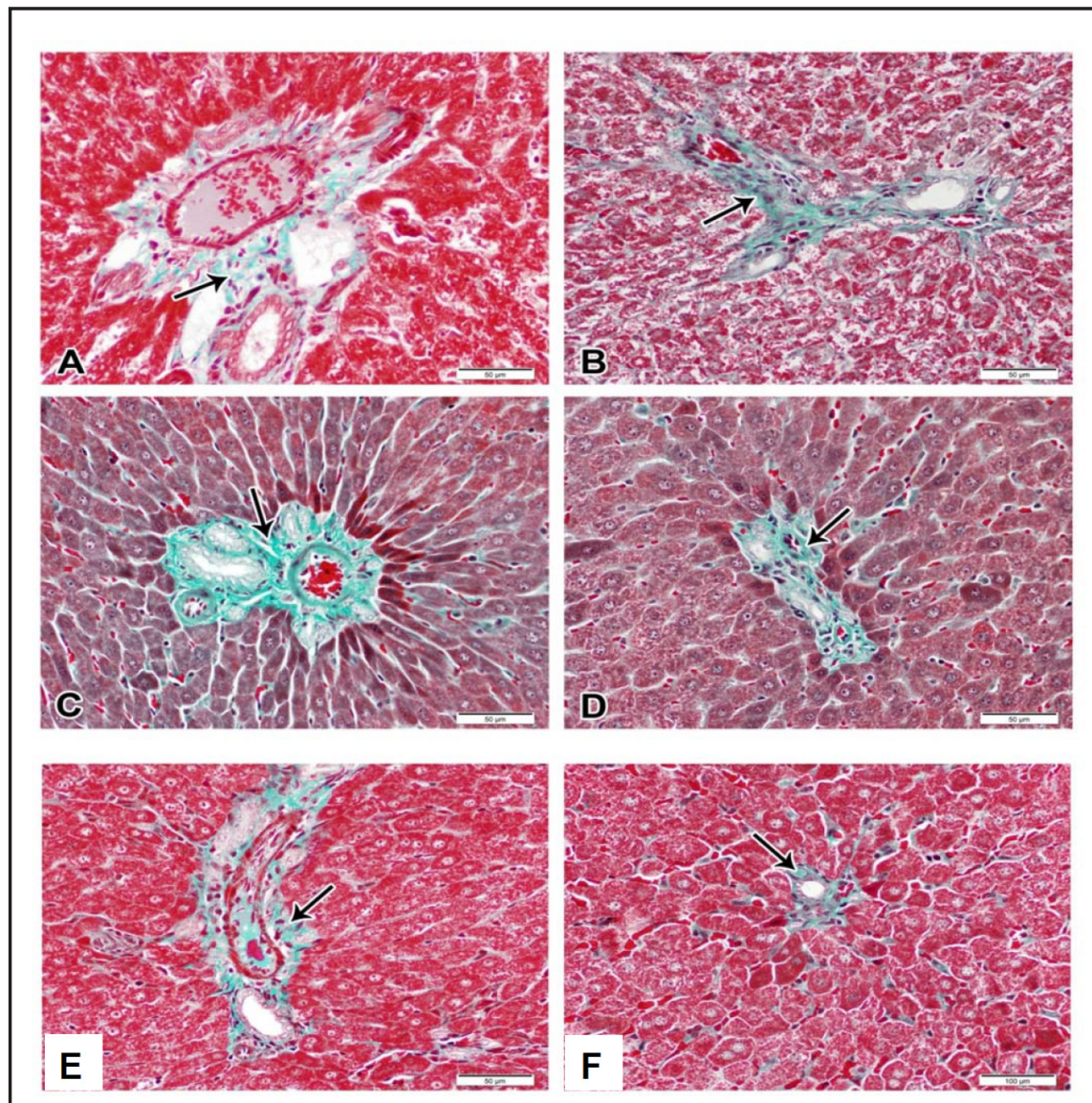

significantly alleviated oxidative stress by increasing reduced glutathione (GSH) content, decreasing the formation of malondialdehyde (MDA), ROS, and oxidized glutathione (GSSG), and retaining the activity of glutathione peroxidase (GPx) and superoxide dismutase (SOD) in liver [33]. Likewise, the antioxidant properties of vitamin $\mathrm{E}$ have been strongly demonstrated in many studies $[12,13]$.

In this study, the over expression of fibrotic factors TGF- $\beta 1$ and Smad-2was observed post $\mathrm{n}-\mathrm{TiO}_{2}$ administration; however, idebenone, carnosine and vitamin $\mathrm{E}$ down regulated these parameters, with the combination regimen showing the most significant effect. TGF- $\beta 1$ is a prominent antiproliferative and profibrogenic cytokine that signals through the TGF- $\beta$ receptor (T $\beta R$ ), which in turn phosphorylates Smads at the smad homology 2 domain [34]. Perturbation of TGF- $\beta 1$ signaling has been implicated in several developmental disorders and in various human diseases, including cancer, fibrosis and autoimmune diseases [35]. n- $\mathrm{TiO}_{2}$ was found to be a potent inducer and regulator of matrix metalloproteinase-1 (MMP-1) and TGF- $\beta$ expression and activity, partly via an IL-1 $\beta$-dependent mechanism [36]. It has also been reported that the expression of TGF- $\beta$ in mouse liver accelerates hepatocarcinogenesis and enhances DNA damage due to chronic oxidative stress. Thus, the effect of these antioxidants could be related to their ability to alleviate the encountered state of oxidative stress. In harmony, carnosine was reported to inhibit TGF- $\beta$ production and signaling and to increase phosphorylation of Smad1 in hepatic injury $[37,38]$. Vitamin E-treated mice exhibited less severe renal fibrosis through the inhibition of TGF- $\beta 1$ and Smad2/3 protein expression [39]. Moreover, dietary supplementation with vitamin E inhibited hepatocarcinogenesis, reduced chromosomal alterations, abolished iNOS expression and suppressed heat shock protein (HSP) 70 and TGF- $\beta$ expression in mice liver [40].

VEGF has been demonstrated to be a major contributor to angiogenesis, which restores oxygen supply to tissues when blood circulation is inadequate [41]. Nevertheless, the 


\section{Cellular Physiology Cell Physiol Biochem 2015;35:2402-2411

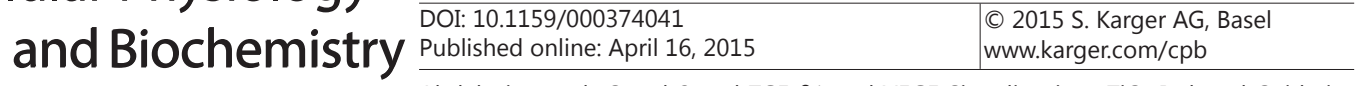 Abdelazim et al.: Smad-2 and TGF- $\beta 1$ and VEGF Signaling in $\mathrm{n}$ - $\mathrm{TiO}_{2}$ Induced Oxidative Injury}

stimulation of angiogenesis may lead to the transition from acute to chronic inflammation [42]. More importantly, oxidative stress was found to potently stimulate VEGF protein and mRNA levels [43]. In this study, there was an over expression of VEGF, accompanied by a significant elevation in $\mathrm{NOx}$ post $\mathrm{n}-\mathrm{TiO}_{2}$ administration; however, the tested antioxidants, especially in combination, ameliorated these changes. In agreement, it has been reported that the administration of $\mathrm{n}-\mathrm{TiO}_{2}$ caused a significant increase in serum immuno-inflammatory biomarkers, including VEGF and NO, with a concomitant decrease in GSH content in renal tissue. Meanwhile, the effect of idebenone may be related to its antioxidative and radical scavenging properties [44]. In the same manner, carnosine treatment prevented retinal vascular damage via normalization of the increased angiopoietin-2 and VEGF levels in diabetic retina [45]. Vitamin E significantly reduced VEGF expression through oxidative stress reduction [46].

\section{Conclusion}

Treatment with idebenone, carnosine, and vitamin $\mathrm{E}$ alone and in combination alleviated the $\mathrm{n}-\mathrm{TiO}_{2}$-induced alterations in the previous biomarkers and effectively reduced histopathological changes. The combination of these three antioxidants showed a somewhat more potent effect, which may be related to their ability to attenuate the liberation of ROS and inflammatory mediators, as well as angiogenic factors. This study merits the use of this combination in ameliorating the risk factors induced by metal NPs.

\section{Abbreviation}

$\mathrm{N}-\mathrm{TiO}_{2}$ (Nano-titanium dioxide); TGF (Transforming growth factor); VEGF (Vascular endothelium growth factor); Hep G2 (Hepatic cell lines); NOx (Nitric oxide); PCR (Polymerase chain reaction); Smad-2 ( Small mother against decapentaplegic).

\section{Disclosure Statement}

The authors have no conflicts of interest to declare.

\section{Acknowledgment}

For the National Research Center for the financial support.

\section{References}

1 Cunningham BW, Orbegoso CM, Dmitriev AE, Hallab NJ, Sefter JC, McAfee PC: The effect of titanium particulate on development and maintenance of a posterolateral spinal arthrodesis. an in vivo rabbit model. Spine 2002;27:1971-1981.

2 Lynch I, Dawson KA, Linse S: Detecting cryptic epitopes created by nanoparticles. Sci STKE 2006;14.

3 Borm PJ, Robbins D, Haubold S, Kuhlbusch T, Fissan H, Donaldson K, Schins R, Stone V, Kreyling W, Lademann J, Krutmann J, Warheit D, Brown JS, Zeman KL, Bennett WD: Ultrafine particle deposition and clearance in the healthy and obstructed lung. Am J Respir Crit Care Med 2002;166:1240.

4 Wang JX, Zhou GQ, Chen CY, Yu HW, Wang TC, Ma YM, Jia G, Gao YX, Li B, Sun J, Li YF, Jia F, Zhao YL, Chai ZF: Acute toxicity and biodistribution of different sized titanium dioxide particles in mice after oral administration. Toxicol Lett 2007;168:176-185.

5 Armand L, Dagouassat M, Belade E, Simon-Deckers A, Le Gouvello S, Tharabat C, Duprez C, Andujar P, Pairon J, Boczkowski J, Lanone S:Titanium Dioxide Nanoparticles Induce Matrix Metalloprotease 1 in Human Pulmonary Fibroblasts Partly via an Interleukin-1 $\beta$-Dependent Mechanism. Am J Res Cell Mol Biol 2013;48:354-363.

6 Valencia S, Gretzer C, Cooper LF: Surface nanofeature effects on titanium-adherent human mesenchymal stem cells. Int J Oral Maxillofac Implants 2009;24:38-46. 
Abdelazim et al.: Smad-2 and TGF- $\beta 1$ and VEGF Signaling in $\mathrm{n}$ - $\mathrm{TiO}_{2}$ Induced Oxidative Injury

$7 \quad$ Ghulam RL, and Dileep KR:Targeting apoptosis with compounds from commonly used medicinal plants: A possible aid in the fight against cancer. Med Hypothesis Res 2006;3:10.

8 Ali SA, Aly HF, Faddah LM, Zaidi ZF: Dietary supplementation of some antioxidants against hypoxia. World J Gastroenterol 2012;28:6379-6386.

9 Parnetti L: Clinical pharmacokinetics of drugs for Alzheimers disease. Clinpharmcokinet 1995;29:110-129.

10 Torii H, Yoshida K, Kobayashi T: Disposition of idebenone (CV-2619) a new cerebral metabolism improving agent, in mice and dogs. J Pharmacobiodyn 1985;8:457-467: 42-51.

11 Ali SA: Evaluation of immunological effect of beta alanyl-l-histidine against Schistosoma mansoni antigens of Rabbits. J Infect Dev Ctries 2012;6:166-175.

12 Schaffer S, Muller WE, Eckert GP: Tocotrienols constitutional effects in aging and disease. J Nutr 2005;135:151-154.

13 Zingg JM: Modulation of signal transduction by vitamin E. Mol Aspects Med 2007;28:481-500.

14 Qureshi AA, Reis JC, Qurush N, Papasian CJ, Morrison DC, Schaefer DM: $\delta$-Tocotrienol and quercetin reduce serum levels of nitric oxide and lipid parameters in female chickens. Lipids in Health and Disease 2011;10:39-58.

15 Li N, Ma L, Wang J, Zheng L, Liu J, Duan Y, Liu H, Zhao X, Wang S, Wang H, Hong F: Interaction between nano-anatase TiO2 and liver DNA from mice in vitro.Nanoscale Res Lett 2010;5:108-115.

16 Gunnar M, Buyse GM, Michael E, Jan D, Erik V, Alejandro J, An Van DB, Luc M, Isabelle CF, Patrizia B, Thomas:Long-term blinded placebo-controlled study of SNT-MC17/idebenone in the dystrophin deficient mdx mouse: cardiac protection and improved exercise performance. Eur Heart J 2009;30:116-124.

17 Zhang X, Song L, Cheng X, Yang Y, Luan B, Jia L, Xu F, Zhang Z: Carnosine pretreatment protects against hypoxia-ischemia brain damage in the neonatal rat model. Eur J Pharmacol 2011;667:202-207.

18 Ishrat T, Parveen K, Hoda MN, Khan MB, Yousuf S, Ansari MA, Saleem S, Islam F: Effects of Pycnogenol and Vit $\mathrm{E}$ on cognitive deficits and oxidative damage induced by intracerebroventricular streptozotocin in mice. Behav Pharmacol 2009;20:567-575.

19 Bassem S, Walid F, Khaled M, Salwa M, May E, Maria HO, Stig L: Screening of natural products for Therapeutic activity against solid tumors. Indian J of Exp Biol 2010;48:258-264.

20 Reitman S, Frankle S: A colorimetric method for determination of serum glutamic oxaloacetic and glutamic pyruvic transaminases. Am J Clin Path 1957;28.

21 Ou BX, Huang DJ, Hampsch-Woodill M, Flanagan JA, Deemer EK: Analysis of antioxidant activities of common vegetables employing oxygen radical absorbance capacity (ORAC) and ferric reducing antioxidant power (FRAP) assays: a comparative study. J Agric Food Chem 2002;50:3122-3128.

22 Jocelyn PC: Biochemistry of the SH Group. Academic Press, London 1972; 10.

23 Miranda KM, Espey MG, Wink DA: A rapid simple spectrophotometric method for simultaneous detection of nitrate and nitrite.Nitric Oxide 2001;5:62-71.

24 Liu B, Zhang X, Zhang FC, Zong JB, Zhang W, Zhao Y:Aberrant TGF- $\beta 1$ signaling contributes to the development of primary biliary cirrhosis in murine model.World J Gastroenterol 2013;19:5828-5836.

25 Grünblatt E, Mandel S, Maor G, Youdim MB: Effects of R-apomorphine and S-apomorphine on MPTPinduced nigro-striatal dopamine neuronal loss. J Neurochem 2001;77:146-156.

26 Bancroft JD, Stevens A: Theory and Practice of Histological Techniques.4 ed., Churchill Livingstone. London 1996.

27 Xiong D, Fang T, Yu L, Sima X, Zhu W: Effects of nano-scale TiO2, ZnO and their bulk counterparts on zebra fish acute toxicity oxidative stress and oxidative damage. Sci Total Environ 2011;409:1444-1452.

28 Sayes CM, Fortner JD, Guo W, Lyon D, Boyd A, Ausman K, Tao Y, Sitharaman B, Wilson L, Hughes J, West J, Colvin V: The differential cytotoxicity of water soluble fullerenes. Nano Lett 2004;4:1881-1887

29 Baykara B, Tekmen I, Pekcetin C, Ulukus C, Tuncel P, Sagol O, Ormen M, Ozogul C: The protective effects of carnosine and melatonin in ischemia-reperfusion injury in the rat liver.ActaHistochem 2008;111:42-51.

30 Velanganni AA, Balasundaram C: Effect of antioxidant vitamins A, C, E and their analogues on azo-dye binding protein in liver of rats treated with p-dimethylaminoazobenzene. Indian J Exp Biol 2010;48:373377.

31 Ma LL, Liu J, Li N, Wang J, Duan YM, Yan JY, Liu HT, Wang H, Hong FS: Oxidative stress in the brain of mice caused by translocated nanoparticulate TiO2 delivered to the abdominal cavity. Biomaterials 2010;31:99105. 


\section{Cellular Physiology Cell Physiol Biochem 2015;35:2402-2411 \begin{tabular}{l|l} 
and Biochemistry Published online: April 16, 2015 & $\begin{array}{l}\text { C) 2015 S. Karger AG, Basel } \\
\text { www.karger.com/cpb }\end{array}$ \\
\hline
\end{tabular} \\ Abdelazim et al:: Smad-2 and TGF- $\beta 1$ and VEGF Signaling in $\mathrm{n}-\mathrm{TiO}_{2}$ Induced Oxidative Injury}

32 Liu HT, Ma LL, Zhao JF, Liu J, Yan JY, Ruan J, Hong FS: Toxicity of nanoanatase TiO2 to mice liver injury oxidative stress. Toxicol Env Chem 2010;92:175-186.

33 Yan SL, Wu ST, Yin MC, Chen HT, Chen HC: Protective effects from carnosine and histidine on acetaminophen-induced liver injury. J Food Sci 2009;74: 259-265.

34 Derynck R, Zhang YE: Smad-dependent and Smad-independent pathways in TGF-beta family signalling. Nature 2003;425:577-584.

35 Kikuchi K, Tanaka A, Matsushita M, Kitazawa E, Hosoya N, Kawashima Y, Selmi C, Gershwin ME, Miyakawa $\mathrm{H}$ : Genetic polymorphisms of transforming growth factor beta-1 promoter and primary biliary cirrhosis in Japanese patients. Ann N Y Acad Sci 2007;1110:15-22.

36 Armand L, Dagouassat M, Belade E, Simon-Deckers A, Le Gouvello S, Tharabat C, Duprez C, Andujar P, Pairon J, Boczkowski J, Lanone S: Titanium Dioxide Nanoparticles Induce Matrix Metalloprotease 1 in Human Pulmonary Fibroblasts Partly via an Interleukin-1 $\beta$-Dependent Mechanism. Amer J Resp Cell Mol Biol 2013;48:354-363.

37 Köppel H, Riedl E, Braunagel M, Sauerhoefer S, Ehnert S, Godoy P, Sternik P, Dooley S, Yard BA: L-carnosine inhibits high-glucose-mediated matrix accumulation in human mesangial cells by interfering with TGF- $\beta$ production and signalling. Nephrol Dial Transplant 2001;26:3852-3858.

38 Ito-Kato E, Suzuki N, Maeno M, Takada T, Tanabe N, Takayama T, Ito K, Otsuka K: Effect of carnosine on runt-related transcription factor-2/core binding factor alpha-1 and Sox 9 expressions of human periodontal ligament cells. J Periodontal Res 2004;39:199-204.

39 Tasanarong A: Vitamin E ameliorates renal fibrosis by inhibition of TGF-beta/Smad2/3 signaling pathway in UUO mice. J Med Assoc Thai 2011;94:S1-9.

40 Calvisi DF, Ladu S, Hironaka K, Factor VM, Thorgeirsson SS: Vitamin E down-modulates iNOS and NADPH oxidase in c-Myc/TGF-alpha transgenic mouse model of liver cancer. J Hepatol 2004;41:815-822.

41 Ding YH, Luan XD, Li J: Exercise-induced over expression of angiogenic factors and reduction of ischemia/ reperfusion injury in stroke. Curr Neurovasc Res2004;1:411-420.

42 Prior BM, Yang HT, Terjung RL: What makes vessels grow with exercise training?. J Appl Physiol 2004;97:1119-1128.

43 Jackson JR, Seed MP, Kircher CH, Willoughby DA, Winkler JD: The codependence of angiogenesis and chronic inflammation. FASEB J 1997;11:457-465.

44 Al-Rasheed NM, Faddah LM, Mohamed AM, Abdel Baky NA, Mohammad RA: Potential Impact of Quercetin and Idebenone against Immuno- inflammatory and Oxidative Renal Damage Induced in Rats by Titanium Dioxide Nanoparticles Toxicity. J Oleo Sci 2013;62:961-971.

45 Pfister F, Riedl E, Wang Q, Vom Hagen F, Deinzer M, Harmsen MC, Molema G, Yard B, Feng Y: Hammes HP. Oral carnosine supplementation prevents vascular damage in experimental diabeticretinopathy. Cell Physiol Biochem 2011;28:125-136.

46 Nespereira B, Pérez-Ilzarbe M, Fernández P, Fuentes AM, Páramo JA, Rodríguez JA:Vitamins C and E down regulate vascular VEGF and VEGFR-2 expression in apo-lipoprotein-E-deficient mice. Atherosclerosis 2003;171:67-73. 